Roberto Galaverni

\title{
Niezwykły użytek z życia i poezji. O Wisławie Szymborskiej ${ }^{*}$
}

\begin{abstract}
Galaverni Roberto, Niezwykły użytek z życia i poezji. O Wisławie Szymborskiej [The unusual use of life and poetry. On Wisława Szymborska]. „Przestrzenie Teorii” 26. Poznań 2016, Adam Mickiewicz University Press, pp. 255-267. ISSN 1644-6763. DOI 10.14746/pt.2016.26.18.

This article is of a comparative nature and attempts to contrast the poetic output of two Nobel prize-winners, i.e. Eugenio Montale and Wisława Szymborska. The author uncovers numerous similarities especially between Montale's late works and Szymborska's poetry. This is particularly visible on two planes, i.e. existential reflection and language, as well as poetic means. The Italian poet and Polish poetess focus on the individual presented as being under pressure from the modern world's vast, impersonal forces, e.g. history, progress etc. They treat the traditional poetic means of expression with mistrust and instead favour the kind of language that is as clear as possible, subject to philosophical reflection, and infused with irony, allegory and paradox.
\end{abstract}

Pierwszą książką Wisławy Szymborskiej, którą przeczytałem - dwadzieścia lat temu - byli Ludzie na moście. Nie przypominam sobie, czy podobieństwa między jej poezją - czy raczej jej sposobem uprawiania poezji - a twórczością późnego Montalego uderzyły mnie już wówczas, ale zastanawiałem się nad nimi od pewnego czasu. Spróbuję wyjaśnić, co mam na myśli, a także dlaczego paralela pomiędzy poetą bólu istnienia (tyleż, co jego rozkładu, a w istocie wręcz miazgi istnienia, które zaznaczyły się w jego późniejszej twórczości) a poetką uśmiechu i radości przynajmniej radości pisania - może wydać się niektórym od razu mocno dyskusyjna. Jest wszelako także i inny powód. Rozwijając moją argumentację, będę również mieć okazję do tego, by wyjaśnić, jak odczytuję poezję Szymborskiej.

Na początek dwie uwagi. Montale, którego określam jako późnego, ostatniego, starego jest, w istocie, poetą wewnętrznie zróżnicowanym, tak jak różnią się między sobą jego trzy ostatnie książki: Satura, Diario del'71 e del' 72 oraz Quaderno di quatro anni. Określenia te wydają się jednak praktyczne, a w każdym razie zasadne, i odnoszą się do jego twórczości od chwili, gdy pewne elementy wspólne - widoczne szczególnie

* R. Galaverni, Per un uso non ordinario della vita e della poesia. Su Wistawa Szymborska, [w:] Szymborska, la gioia di leggere. Lettori, poeti, critici, a cura di Donatella Bremer e Giovanna Tomassucci, Pisa University Press, Pisa 2016. Redakcja „Przestrzeni Teorii” składa podziękowania włoskiemu wydawnictwu Pisa University Press za zgodę na tłumaczenie na język polski i druk tekstu. 
w kontraście do jego wcześniejszej poezji - stają się od dłuższego już czasu dominujące i niezaprzeczalne. Uwaga druga odnosi się do mojego stosunku do poezji Szymborskiej, której znajomość, ze względu na to, że zupełnie nie znam języka polskiego, jest zapośredniczona przez przekłady. Moje uwagi odnoszą się zatem do tekstów przełożonych - w tym przypadku, prawie w całości - przez Pietra Marchesaniego, którego pracy muszę zaufać, w każdym aspekcie. Właśnie z tego powodu z niechęcią odnoszę się do sytuacji, w których - a tak jest właśnie w przypadku Szymborskiej - jakieś dzieło ważnego pisarza jest niejako zamknięte wyłącznie w jednym przekładzie. Niezależnie od talentu tłumacza i wartości rezultatów jego pracy, jak również, rzecz jasna, jego wpływu i zasług na polu inicjatywy przekładowej, niemożliwe jest w takiej sytuacji porównanie różnych przykładów, a przez to także wyrobienie sobie szerszej i tym samym pełniejszej opinii na temat dzieła oryginalnego. Szymborska, którą wszyscy czytamy, to, Szymborska-Marchesani. Zupełnie inaczej, jak sądzę, mają się sprawy z przekładami na przykład poezji Seamusa Heaneya. Te z nich, które opracowali najlepsi tłumacze jego twórczości, tacy jak Buffoni, Mussapi, Fusini, Guerneri, Sacerdoti, Sonzoni, są rozpoznawalne i idiosynkratyczne, dzięki czemu wzbogacają się nawzajem.

W każdym razie, moje wrażenie, które dojrzewało długo ostatnimi laty (i którego nie zmieniło tłumaczenie trzydziestu wierszy noblistki ze zbioru Wystarczy [Basa così], przygotowane przez Silvana De Fantiego, a wydane już po śmierci tak samej poetki, jak i jej wiernego włoskiego tłumacza), jest takie, że poezja Szymborskiej pozostaje w swej istocie niezmienna, od kiedy zyskała dojrzałość wyrazu (przyjmijmy, że miało to miejsce wraz z publikacją tomu Wotanie do Yeti, 1957 [Appello allo Yeti]); to samo wrażenie dotyczy przede wszystkim przekładalności jej wierszy, co, zważywszy, że mamy do czynienia z poezją, mówi wiele samo z siebie. Marchesani, jak każdy znakomity tłumacz, przyjął rozwiązania translatorskie raz bardziej, raz mniej przekonujące, jednak brawurowy przekład brawurowych tekstów, przez częste wykorzystywanie rymów, gier słownych, paralelizmów, jak też wewnętrznych odniesień (myślę na przykład o wierszach Urodziny [Compleanno] czy Zdziwienie [Stupore], oba z tomu Wszelki wypadek [Ogni caso], s. 309 i 307), wskazuje na uwrażliwienie na ekspresyjny oraz autoreferencjalny wymiar języka. Powiedziałbym, że w przypadku Szymborskiej, pominąwszy pewne wyjątki, ryzyko zagubienia sensu w przekładzie jest stosunkowo mniejsze niż w przypadku innych poezji i innych poetów. Pewne zakłopotanie rodzi się nawet a contrario: w końcu zadaje się pytanie - to oczywiście moje doświadczenie lekturowe - czy także w oryginale wszystko było takie jasne i proste, na swoim miejscu, bezpośrednio referencjalne. Tak czy inaczej, poezja 
Szymborskiej, także ta wydana pośmiertnie, potwierdza przewagę wymiaru wertykalnego, czyli kolokwialnego, dyskursywnego, argumentacyjnego nad wymiarem horyzontalnym. Język, przynajmniej zasadniczo, nie tyle zwraca się ku sobie samemu, ile służy jako nośnik dla wyrażenia treści, które chce przekazać. Funkcjonalność i instrumentalny charakter języka przeważają stanowczo nad jego autonomią; jego przejrzystość wobec treści ma na celu usunięcie wszelkiej nieprzejrzystości, zniwelowanie jej tak, jakby ta ostatnia była przeszkodą, tamą dla swobodnego przepływu sensu. Dyskurs, argumentacja, przejrzystość, przekładalność - dokładnie jak u późnego Montalego.

By nie powtarzać tego, co już powiedziano, przywołam syntetyczny i precyzyjny opis poezji Szymborskiej, dokonany przez Alfonsa Berardinellego, czyli krytyka, który być może odnalazł największe współbrzmienie między własnym ideałem poezji a tym, co faktycznie mówią wiersze poetki.

Każdy czytelnik może dostrzec w poezji Szymborskiej wiele cech, które wzięte razem czynią ją nieporównywalną. Wymienię niektóre z nich: wyzwolona wyobraźnia i sytuacje dnia codziennego; skłonność do humoru, nawet komizmu; gry słowne ściśle powiązane z grą idei i obrazów; dialektyka kompozycji, która zderza $\mathrm{z}$ sobą nawzajem przeciwieństwa, a w tym, co tożsame $\mathrm{z}$ sobą, odkrywa sprzeczności; ironia i patos, które powstają jedna z drugiego; intelektualna śmiałość i natchnienie, którym towarzyszy techniczna maestria ${ }^{1}$.

I dalej, Berardinelli wskazuje na „podstawową, higieniczną funkcję odtruwania tego, kto czyta z pojęć ogólnych, które przeradzają się w idole i mity, jeśli tylko pozwolimy im oderwać się od konkretnych sytuacji”, ale też na „większą, niż w przypadku innych pisarzy, odporność tej poezji na ryzyka płynące z przekładu". Moim zdaniem, wszystkie te charakterystyki można odnieść bez wyjątku także do późnego Montalego. I faktycznie od momentu ukazania się Satury wskazywano zgodnie na takie cechy jego poezji, jak ironia, sprzeczności, odwracalność pojęć, argumentacyjność, dyskursywność bądź kolokwialność osiągnięte dzięki metryce, nieustanna zmiana punktu widzenia, upodobanie do intelektualnej prowokacji oraz paradoksu, sprzeciw wobec stereotypów, umysłowej inercji, postępowych mitów, i wiele innych (krytycy różnili się między sobą $\mathrm{w}$ ocenie wartości tej poezji, nie w rozpoznaniu jej cech charakterystycznych). Zawsze jest jakaś „druga strona medalu”, przypomina, cytując Szymborską, Bernardinelli, by ukazać istotę jej poetyckiego myślenia.

1 A. Berardinelli, Wistawa Szymborska in Italia: perché ci mancava, [w:] Szymborska, la gioia di leggere. Lettori, poeti, critici, red. D. Bremer, G. Tomassucci, Pisa 2016, s. 87-91. 
Montale to, w sposób szczególny, poeta drugiej strony medalu. „Prawda i fałsz to awers i rewers / tego samego medalu" pisze w wierszu Il frullato $\mathrm{z}$ tomu Diario del '71 e del' 722, doprowadzając aż do granic relatywizmu to, co u Szymborskiej (i na tym właśnie zasadza się różnica między włoskim poetą a poetką polską) jest natomiast odczuciem problematycznej względności. Ten katalog podobieństw można jeszcze, oczywiście, uzupełnić o inne cechy wspólne, poczynając od sięgania po dygresje, wykorzystywanie tautologii, antyfrazy, odwrócenia. Nietrudno zauważyć, że na tych właśnie zabiegach Montale oparł ostatnią fazę swej poezji. Ileż jego wierszy - podobnie jak wierszy Szymborskiej - rozwija się poprzez niespodziewane odwrócenie początkowych stwierdzeń, które okazują się tezami zaprzeczonymi, przynależnymi do sfery stereotypu, wiedzy naukowej, poznania filozoficznego, przekonań politycznych, etycznych pewników, rozpowszechnionych zwyczajów i zachowań, obowiązujących w danym momencie teorii (na przykład na temat języka), czy zwłaszcza kultury literackiej i poetyckiej! Oto jeden z najdobitniejszych przykładów, strofa, którą zaczyna się Pierwsza miłość (Il primo amore) z tomu Szymborskiej Chwila [Attimo 2002]: „Mówią, że / pierwsza miłość najważniejsza. / To bardzo romantyczny, / ale nie mój przypadek". Następnie, także z punktu widzenia poruszanych tematów, ileż razy Montale zderza nie tylko, jak czynił to wcześniej, to, co podniosłe, z tym, co prozaiczne, lecz także - a podobnie, przypomnijmy raz jeszcze, rzeczy mają się w przypadku Szymborskiej - wymiar kosmiczny z codziennością, wymiar metafizyczny z życiem codziennym, różnicę z tym, co niezróżnicowane, niepowtarzalną jednostkę z wielką liczbą! Ileż razy i Montale i Szymborska, oscylując wciąż między tym, co szczególne, a tym, co powszechne, między jednostkowością a uogólnieniem, zmuszają nas - on z szelmowskim uśmiechem, ona tańcząc na koniuszkach palców - do przyglądania się czasowi, Historii, postępowi i regresowi, złu i dobru, końcowi i początkowi, codziennemu życiu, ludzkiej społeczności, naturze i jej rytmom!

„Jak każdy prawdziwy poeta, Montale nie jest uczonym, nie przekazuje nam jakichś informacji, lecz odkrywa i - każe nam myśleć”, napisał a propos Quaderno di quattro anni Cesare Garboli. I dla Montalego, i dla polskiej poetki charakterystyczna jest absolutyzacja doświadczenia, i to nie tylko osobistego - czy chodzi o pochwałę tego, co jednostkowe i niepowtarzalne, bądź tego, co stanowi dziedzictwo (lub przeciwnie - co jest ciężarem) ludzkiego gatunku, czy też o ukazanie odwracalności czasu, jednostronnych perspektyw, przesądów, arbitralnego charakteru po-

2 Zob. E. Montale, L'opera in versi, a cura di R. Bettarini e G. Contini, Torino 1980, s. 443. 
wszechnie przyjętych podstaw epistemologicznych, nieprzewidywalności życia, a jednocześnie jego nieugiętych praw. Jeśli sięgają po szkło powiększające, to czynią to, by nabrać dystansu, ustalić właściwą miarę zjawisk, czyli odnieść to, co poszczególne do jakiegoś prawa, nawet jeśli jest to prawo poszczególności. Nierzadko wykorzystują przykłady i przypadki wzorcowe (ileż wyliczeń w ich wierszach, zwłaszcza u Szymborskiej), sięgając po tematy filozoficzno-antropologiczne, zawsze $\mathrm{z}$ intencją przeniesienia tego, co pojedyncze na wyższy poziom poznania. Wyciągają wnioski, dobywając $\mathrm{z}$ określonego zdarzenia jakiś morał. Za konstatacją idzie zawsze konceptualizacja; nie pozostają zatem przy jakimś fakcie, lecz wykraczają poza niego, by ukazać jego kod, DNA o charakterze zasadniczo moralnym. Stąd skłonność do alegorii, filozoficznej opowiastki o charakterze demonstratywnym, gnomicznych klauzul, ujęć epigramatycznych, anafor. Podstawowy ton poezji i Szymborskiej, i Montalego jest syntetyczny, eksplikatywny, komentatorski, eseistyczny. To nie dotyk rzeczy czy materii świata kształtuje formę wyrazu, lecz przeciwnie rozmyślanie o rzeczach i świecie. Już same tytuły wierszy, takie jak Widziane $z$ góry (z Wielkiej liczby), czy jeszcze bardziej Ktoś, kogo obserwuje od pewnego czasu otwierający tom Wystarczy, obrazują, jak sądzę, sposób poetyckiego ujęcia rzeczywistości przez Szymborską. Tak właśnie kończy się wiersz Widziane z góry (a mógłbym przytoczyć również Przymus z tomu Wystarczy, który mówi to samo).

I oto ten na drodze martwy żuk

w nieopłakanym stanie ku słonku polśniewa.

Wystarczy o nim tyle pomyśleć, co spojrzeć:

wygląda, że nie stało mu się nic ważnego.

Ważne związane jest podobno $\mathrm{z}$ nami.

Na życie tylko nasze, naszą tylko śmierć,

śmierć, która wymuszonym cieszy się pierwszeństwem.

Słowa te brzmią jak odpowiedź na to, co Montale - podobnie stawiając pod znakiem zapytania antropocentryzm - napisał zaledwie kilka lat wcześniej w epigramatycznym wierszu Il dottor Schweitzer z tomu Diario del '71 e del '72:

Rzucałem żywe ryby głodnym pelikanom

Wyszło na jaw, że także ryby to życie, lecz

Niższego poziomu

A do jakiego my należymy

I w czyjej gardzieli?... Tu zamilkł teolog

Otarł pot z czoła ${ }^{3}$.

3 Tamże, s. 450. 
Faktycznie, pod wieloma względami, zasadniczymi, dotyczącymi pojmowania rzeczywistości: sensu (w istocie bezsensu) Historii, (nie)wspaniałego i (nie)postępowego przeznaczenia, relacji między człowiekiem jako cząstką kosmosu a kosmosem, przypadkowości ludzkiego życia - oboje myślą w sposób zadziwiająco podobny. Kiedy leciwy poeta nie traktuje już rozgoryczenia jako przesądu, kiedy Szymborska nie wiąże już dłużej ludzkiego poznania z życzliwością, nie mówiąc o dobroci, podobieństwa między nimi wychodzą na jaw z całą jasnością. Tak jest choćby w przypadku nie naturalnego, lecz arbitralnego charakteru relacji tego, co wysokie, i tego, co niskie, tego, co przed, i tego, co po. Z wieloma tekstami Montalego, które zacierają granice między uprzedniością, funkcjami i prawdopodobieństwami (przykładem wiersz $\mathrm{Ci}$ si rivede mi disse qualcuno ${ }^{4}$, można zestawić tę dezorientującą grę odbić między tym, co po tej, a tym, co po tamtej stronie, którą Szymborska inscenizuje w Rachunku elegijnym. Można $\mathrm{z}$ nimi zestawić także alternatywę konieczności i przypadkowości ogólnego planu rzeczywistości, wspomnianą w Może to wszystko, alternatywę, która w istocie sprowadza się do braku różnicy między opozycjami, znoszącymi się nawzajem:

\author{
Może to wszystko \\ Dzieje się w laboratorium? \\ [...] \\ Może jesteśmy pokolenia próbne? \\ [...] \\ Może inaczej: \\ Żadnych interwencji? \\ Zmiany zachodzą same \\ Zgodnie z planem? \\ [...] \\ Może przeciwnie: \\ Gustują tam wyłącznie w epizodach? \\ [...] \\ Zawiadomić Szefa, \\ Niech przyjdzie i sam popatrzy!
}

(trudno tu nie pomyśleć o tylu demiurgach, bóstwach, bogach i ich różnych podgatunkach, o architektach, projektantach i skrybach występujących u Montalego, począwszy od Satury).

Podobnie w przypadku rozdarcia pomiędzy postępem naukowym i technicznym a szczęściem człowieka; jest to prawdziwy lejtmotyw poezji późnego Montalego, pojawia się też wiele razy u Szymborskiej (na przy-

4 Tamże, s. 602. 
kład w wierszu Nadmiar: „Odkryto nową gwiazdę, / co nie znaczy, że zrobiło się jaśniej / i że przybyło czegoś czego brak"). Nie inaczej sprawy mają się też ze sceptycyzmem pod adresem wszystkich mitów postępowych, na czele $\mathrm{z}$ materializmem dialektycznym (zasada tertium non datur obowiązuje w przypadku i Montalego, i Szymborskiej), na którego miejsce wchodzi pewien rodzaj dualistycznego immanentyzmu, jak to się dzieje w Krótkim życiu naszych przodków:

\author{
kiedy zło tryumfuje, dobro się utaja; \\ gdy dobro się objawia, zło czeka w ukryciu. \\ Jedno i drugie nie do pokonania \\ ani do odsunięcia na bezpowrotną odległość. \\ Dlatego jeśli radość, to z domieszką trwogi, \\ jeśli rozpacz, to nigdy bez cichej nadziei. \\ Życie, choćby i długie, zawsze będzie krótkie. \\ Zbyt krótkie, żeby do tego coś dodać.
}

Jak trudno właściwe rozpoznać historyczno-filozoficzne podstawy, z których wyrastają wiersze Szymborskiej... Kiedy myślimy czy to o jej uśmiechu, czy też o mroczniejszej stronie jej poezji, powinniśmy pamiętać o tym, co pisze w ostatniej zwrotce Uśmiechów:

Ludzkość braterska, zdaniem marzycieli,
zamieni ziemię w krainę uśmiechu.
Wątpię. Mężowie stanu, dajmy na to,
uśmiechać by się tyle nie musieli.
Tylko czasami: że wiosna, że lato,
bez nerwowego skurczu i pośpiechu.
Istota ludzka smutna jest z natury.
Na taką czekam i cieszę się z góry.

Z pary omawianych tu poetów Montale wydaje się nawet bardziej wierzyć $\mathrm{w}$ możliwości, choć wyczuwa się u niego tęsknotę za jakimś uchwytnym porządkiem, za stanem rzeczywistości, który byłby mniej płynny, mniej pomieszany, bez ładu i składu, czyli pozbawiony jakiegokolwiek ukierunkowania. Często to właśnie ta nostalgia, częściowo egzystencjalna, częściowo metafizyczna, dyktuje mu najpiękniejsze wiersze i poetyckie chwyty, według mnie wręcz unikalne, w których najwyraźniej bez żadnego wysiłku ze strony poety jego język staje się jednocześnie prosty i precyzyjny, bezpośredni, wolny od poetyckich udziwnień, śmiały, a jednocześnie niezwykle stonowany, tak jakby Montalemu udało się w najlepszy sposób przyswoić sobie nie język poetycki (jak czyni to, na przykład, Giovanni Giudici), lecz włoski używany przez wszystkich. Jest 
to język, który nie musi być koniecznie liryczny, by stać się przewodnikiem intensywności, ani też przewidywalnie prozaiczny, by można w nim było opowiadać - tak, jakby, mówiąc o wszystkim, zdolny był do niewykraczania poza binarności. Jeśli jego włoski jest, co wielokrotnie podkreślano, włoskim przeciętnym, to należy uznać, że ten (jego?) zwykły język (jedno z najbardziej kłopotliwych pojęć, które funkcjonują w polu poetyckim) odznacza się zdumiewającą równowagą i elegancją.

I vice versa: u Szymborskiej cięcie pomiędzy przedtem a potem, pomiędzy początkiem a końcem - czy wręcz nawet ich zawieszenie - jest właśnie tym, co odciska się na jej poezji i jakby tłumaczy właściwy jej tryb. „Duszyczko, tylko wątpiąc w zaświaty / Pełniejsze masz perspektywy" - brzmi konkluzja wiersza Nad Styksem. Skoro przedtem i potem zostają zawieszone, skoro odniesione są do tu i teraz ludzkiego przemijania na świecie, pozostaje tylko chwila. Chwila-życie, najpierw zdewaluowana przez brak dopływów i odpływów, okazuje się tą instancją, w której rozstrzyga się wszystko. Rzecz jasna, takie określenia jawią się jako zbyt linearne, jakby sylogistyczne, podczas gdy w tego rodzaju zjawiskach nie istnieje konsekwencja, nie ma w nich nic mechanicznego czy możliwego do wyjaśnienia jedynie logicznie. Spisek historii i wizji kosmicznej - czy też, by użyć przymiotnika stosowanego przez poetkę: gwiezdnej mógłby wywołać, w ten sam sposób, zupełnie inną (tym bardziej poetycką) odpowiedź. Jest niezaprzeczalnym faktem, że konieczność i chęć Szymborskiej bycia poetką jest właśnie takiej natury: być nią poprzez poezję pozytywną (nie znajduję innego określenia). Albo choćby - założywszy, że każda poezja godna tego imienia zawiera w sobie zawsze siłę i pozytywność jako wewnętrzną zgodność treści formy (Leopardi docet także i w tym względzie) - dzięki poezji, w której pozytywna siła byłaby wręcz deklaratywnie afirmatywna, byłaby pouczeniem moralnym, moralną wskazówką, praktyczną radą, doświadczeniem życiowym, przekazywanym od jednej do drugiej osoby. Właśnie jako to małe dobro, które można przeczytać na jakiejś stronie i odnieść je wprost do własnego życia. Życie jako nauka życia - czyli to, co Szymborska zdecydowała się przekazać (taka jest właśnie jej poetycka odpowiedź) i jest pewną możliwością widzenia nas samych w naszym własnym życiu, z nadzieją na to, że przeżyjemy je lepiej. Nadzieja - to słowa o kapitalnym znaczeniu, bez wątpienia. Nie jest to jednak nadzieja na spełnienie, całość, odkupienie, zbawienie, raczej nadzieja na rzucenie światła na własną - czyli naszą chwilę i znalezienie dla niej usprawiedliwienia.

Jeśli zatem, jak twierdzi, moim zdaniem słusznie, Berardinelli, poezja Szymborskiej jest „niepowtarzalna”, to zawdzięcza tę niepowtarzalność nie tylko, ani nawet nie przede wszystkim, specyficznej stylistyce 
czy retorycznej organizacji, ani też domniemanej oryginalności w wyborze tematów czy motywów, lecz wewnętrznemu powiązaniu wszystkich tych elementów z pewnym całościowym, znamiennym dla noblistki ukierunkowaniem poetyckiego dyskursu. Mam nadzieję, że nawiązanie, które chcę teraz uczynić, nie będzie całkiem od rzeczy - ale jeśli znowu myśli się o późnym Montalem, to jego poezja oraz poezja Szymborskiej jawią się niczym dwa obszary, w których pewne zabiegi i elementy, choć bardzo podobne do siebie, są odmiennie ukierunkowane, niczym dwie sterty nasion, które wiatr rozgania $\mathrm{w}$ różnych, wręcz przeciwnych kierunkach. Odwołując się do występującej w poezji Celana idei inklinacji, powiedziałbym, że to, co odróżnia oba omawiane tu poetyckie światy, to szczególny tembr, dyspozycja, a szczególnie - inklinacja czy też ukierunkowanie poetyckiego głosu. Krótko mówiąc, sądzę, że tym, co czytelnika Szymborskiej uderzy w jej wierszach, tym, co uzna za oryginalne, będzie nie tyle to, co poetka mówi, a nawet nie sposób, w jaki mówi, ile ton, którym się wypowiada - przy czym nie ulega wątpliwości, że wszystkie te aspekty są ściśle z sobą powiązane. Widoczne jest to tym bardziej że - jak to się zdarza $\mathrm{w}$ wielu przypadkach - poezja ta mierzy się $\mathrm{z}$ res gravis ludzkiego losu: przemocą, strachem, niesprawiedliwością, śmiertelnością. Jeśli przypomnimy sobie teraz koncepcję ziarna głosu Barthes'a lub też poszerzymy o całe ekspresyjne spektrum koncepcję koloru samogłosek Rimbauda, to, jak sądzę, w przypadku Szymborskiej należy mówić o świetlistości, blasku, radości, obecności ducha, olśnieniu, życzliwości, zażyłości, zrozumieniu. Do zażyłości z jej wierszami dochodzi się właśnie nie tylko dzięki inteligencji i jej zdobyczom, ile przede wszystkim poprzez uznanie, że wszyscy płyniemy na tej samej łodzi, że wspólny jest nam pęd do lepszego zrozumienia i przeżycia naszego życia. Nieco przesadzając, a w każdym razie bez najmniejszej woli ferowania wyroków na korzyść bądź niekorzyść jednego bądź drugiej, można powiedzieć, że poezja późnego Montalego jest poezją kogoś, kto chce przeżyć, podczas gdy osoba, która mówi i do której się mówi w wierszach Szymborskiej to ktoś, kto jeszcze chce $\dot{z} y c ́$. Montale zresztą wprost mówi o swej późnej poezji jako o poezji pośmiertnej, poezji jako geście wybiegu i wycofania z walki, którą już się przegrało i której, w konsekwencji, nie warto było podejmować. Nieprzypadkowo miłośnicy twórczości poety czują się w obowiązku podkreślać pozytywny charakter i rezydua energii, widoczne w zuchwałej, wręcz perwersyjnej strategii, która polega na przejęciu taktyki przeciwnika $\mathrm{w}$ celu wyminięcia go i przeszkodzenia mu w trafieniu do celu. Wśród wielu przykładów wymienię tylko pracę Zanzottego La freccia dei diari. Zgoła przeciwnie ma się sprawa z Szymborską: czujemy się we- 
zwani do tego, by uznać i oddać sprawiedliwość pozytywnej inklinacji jej poezji.

Nawet jej samej zdarzyło się to uczynić. Od razu uderzył mnie ten oto fragment rozmowy z poetką, która odbyła się na początku 1997 roku.

Uświadomiłam sobie, że ta cała moja historia pozbawiona jest dramatyzmu. Tak jakbym prowadziła życie motylka, jakby życie tylko głaskało mnie po głowie. To jest mój portret zewnętrzny. Ale skąd taki obraz? Czy ja naprawdę taka jestem? Życie miałam właściwie szczęśliwe, jednak było w nim wiele śmierci, wiele zwątpień. Ale ja oczywiście o sprawach osobistych mówić nie chcę, ale też nie lubiłabym, gdyby mówili inni. Co innego po mojej śmierci. Ja mam do ludzi inną twarz, dlatego pokazują mnie od strony anegdotycznej, jako osobę wesołą, która nic, tylko wymyśla gry i zabawy. To, że inni tak mnie widzą, to moja wina. Pracowałam długo na ten wizerunek. Bo jak mam ciężkie zapaści, ciężkie zmartwienia, to do ludzi nie wychodzę, żeby nie pokazywać ponurej twarzy ${ }^{5}$.

Szymborska sytuuje się tu na planie egzystencjalnym, mówi o twarzy, którą pokazujemy innym. Słowa te wydają się jednak mówić więcej, niż jakakolwiek jej bezpośrednia deklaracja dotycząca poezji: słowo „obraz”, którego używa, można uznać w pełni także za jej poetycki portret. Skoro jednak tak jest, to musimy zapytać jej słowami: „Ale z czego się on bierze?". Na pierwszy rzut oka sądzę, że o słynnej radości życia u Szymborskiej możemy mówić tylko jako o radości skonstruowanej, ze wszystkim, co ona z sobą niesie: świadomością zła, przemocy, mroku, bólu, pustki, marności, „śmierci” (sama poetka używa tego ostatniego słowa). A jednak można też mówić o wyborze, woli, decyzji - bo dokładnie o to właśnie tu chodzi - pisania poezji tylko w określony sposób, taki więc, który za każdym razem dałby też możliwość ustanowienia jakiegoś kontrapunktu, będącego też środkiem zaradczym, możliwość głosu, który byłby sam z siebie antidotum, oknem otwartym nie na mrok, lecz na światło.

Za swą cechę charakterystyczną, powiedziałbym wręcz - istotową uznaje poetka zdolność do tego, by nie zastygać $\mathrm{w}$ negatywnych przesądach na temat świata: „Mogłabym być sobą, ale bez zdziwienia, / a to by oznaczało, / że kimś całkiem innym" (W zatrzęsieniu). Trzeba jednak od razu powiedzieć, że ten głos dochodzący od strony życia jest czymś zupełnie innym niż jakaś określona postawa, jest on mianowicie zdobyczą, po którą trzeba sięgać wciąż na nowo na drodze doświadczenia i rozumienia. Codzienny obrządek podlega powtarzaniu, odzyskiwaniu każdego dnia, jak pisze o tym Szymborska w Rzeczywistość wymaga: „Nie bez powabów jest ten straszny świat, / nie bez poranków, / dla których warto się zbu-

5 Cyt. za A. Bikont, J. Szczęsna, Pamiattkowe rupiecie. Biografia Wisławy Szymborskiej, Kraków 2012, s. 8. 
dzić". O ile zło jest za darmo, nie jest takim dobro, za które trzeba nieustannie płacić i które trzeba uzasadniać. Wydaje mi się jednak, że rzeczą niewłaściwą byłoby mówić o powołaniu Szymborskiej do radości. Chodzi tu raczej o pewien wybór: „Wolę brać pod uwagę nawet tę możliwość, / że byt ma swoją rację" (Możliwości). Chwila szczęścia, a tym bardziej, znów mówiąc jej słowami, „szczęśliwe życie”, musi być konstruowane, dokładnie tak, jak te medytacyjne struktury, którymi są jej wiersze. Jak myślę, $\mathrm{i}$ to pierwsze, i te drugie zawierają $\mathrm{w}$ sobie pewien naddatek.

Wszystko to znajduje swój wyraźnie określony kształt w dobrze przemyślanej strategii ekspresji, w inklinacji poetyckiej fizjonomii, które obok tylu zwycięstw odniosły także kilka porażek. Być może nie można ich było uniknąć, być może były ceną za stworzenie poezji, która każdorazowo miałaby być małym świętem, minimalnym choćby dowodem egzystencjalnego i antropologicznego zdrowia (Szymborska wielokrotnie powracała do idei poezji jako święta, przypomnę tylko jedną jej wypowiedź: „Nie każda poezja zdolna jest porywać, jak swego czasu Oda do młodości Mickiewicza, każda jednak powinna stanowić pewną niespodziankę. Określanie jej mianem «zwykłej», «poprawnej», «normalnej» z miejsca ją dyskwalifikuje. Ona nigdy nie jest na każdy dzień, lecz tylko na dni świąteczne, jest owocem wyjątkowości, szczęśliwego przypadku” PL 29-30). Tej perspektywie szczęśliwości oddała wszystko, jak sądzę, nawet możliwość pełnego wykorzystania swej wrażliwości językowej, możliwość zyskania innej, może bardziej osobistej rekompensaty. Szymborska jako nieprzyjaciółka absolutnego mroku, negatywności bez drogi powrotnej, mrocznych otchłani sensu, nie mogła pozwolić na to, by język rozbrzmiewał w sposób nieokreślony, nie mogła dać słowom przyzwolenia na to, by rozchodziły się zbyt daleko i na własny rachunek. Dystans wobec słowa, kontrola sprawowana nad doświadczeniem w języku i poprzez język, to podstawowy warunek jej poezji. Nawet w momentach największego rozdarcia nie mówi dwuznacznie, lecz o dwuznaczności, nie pozwala, by sens bezprawnie się rozpraszał, choć zgadza się na to, by się daleko rozchodził, po to jednak, by ona sama mogła dojść jeszcze dalej. Celowo trzyma się z dala od języka nieprzejrzystego, języka - przeszkody, który nie służy przekazywaniu, używaniu, wyzwalaniu sensu. Jeśli przypomnimy sobie sformułowanie Seamusa Heaneya o władzy języka, w znaczeniu odnoszącym zarazem do dopełniacza podmiotowego, jak i przedmiotowego, to wydaje się, iż u Szymborskiej dominuje bez reszty ten ostatni (czyli władza poety nad językiem) nad tym pierwszym (język, który bezpośrednio przejmuje władzę nad mówieniem). Bez wątpienia jednak w przypadku 
prawdziwego poety (i to jakiego!) powinny zaznaczać się obie możliwości, i to jednocześnie. Stąd właśnie - z niechęci przed poddaniem się dominacji materialności, bezkształtu, niezdeterminowaniu sensu - powstaje, jak sądzę, wrażenie pewnej mechaniczności, przewidywalności, geometryczności, którymi odznacza się jej poetycka dykcja. Tym bardziej że z biegiem czasu utrwala się u niej dość stabilny sposób ukazywania danych czy odkryć, postawionych pod znakiem zapytania, a któremu towarzyszy określona poetycka prezentacja. Wydaje mi się, że tu właśnie należałoby szukać jedynej możliwej - i możliwej do pomyślenia dla poetki, która bierze w ramiona szympansa niczym brata - idei cywilizacji. Szymborska skacze na głęboką wodę, lecz poezja - to małe święto, ten mały triumf witalności, którym poezja być powinna - równa się dla niej wypłynięciu na powierzchnię. W jej rękach poezja jest w o wiele mniejszym stopniu sondą, służącą dotknięciu nieznanego, niż narzędziem do wyjaśnienia go i uchwycenia jego zasady. Dlatego nie wierzy w język - to moje wrażenie przeciętnego czytelnika przekładów jej wierszy - jako w zjawisko, które mogłoby ją rzeczywiście zadziwić bądź przestraszyć, doprowadzić tam, gdzie dojść nie zamierzała. Nie chodzi tu jednak o jakieś ograniczenie, lecz o pewien sposób pisania. W kluczowym, moim zdaniem, fragmencie Nieuwagi Szymborska pisze: „Świat mógłby być odbierany jako świat szalony, / a ja brałam go tylko za zwykły użytek”. Według mnie pierwszy krok niezbędny do czynienia niezwykłego użytku z poezji byłby u Szymborskiej równoznaczny z rzeczywistym zanurzeniem się poezji w życiu, czy raczej - z czynieniem niezwykłego użytku z życia.

Mapa, jeden z wierszy ze zbioru Wystarczy, zdaje się mówić coś, co obowiązuje w przypadku całej poezji Szymborskiej. Zdradziwszy się ze swą sympatią do map („Puszcze są oznaczone kilkoma drzewkami, / między którymi trudno by zabłądzić”), poetka konkluduje:

\footnotetext{
Lubię mapy, bo kłamią.

Bo nie dają dostępu napastliwej prawdzie.

Bo wielkodusznie, z poczciwym humorem

rozpościerają mi na stole świat

nie z tego świata.
}

Jej poezja oczywiście tym wszystkim nie jest, chyba że pominiemy idealny, a tym samym także utopijny potencjał, tkwiący w każdym, zasługującym na to miano poetyckim projekcie (najwnikliwsze uwagi na ten temat pochodzą od Audena). Zauważmy raczej, że mapowanie, zatem także organizacja logiczna i pojęciowa, branie miary, zarys, kadrowanie, cyzelowanie niemożliwego do odkupienia miąższu życia są ozdobą tej poezji, ale także murem, o który rozbiciem się ryzykuje: chropawość, przepastność, 
ostępy i gęstwiny, które się plantuje, poetycki dyskurs, który wślizguje się w kartografię życia. Ale, powtarzam, to jest właśnie sposób, w jaki Szymborska pojmuje siebie jako poetkę. Italo Calvino, nie przypadkiem najbardziej racjonalistyczny i oświeceniowy z naszych pisarzy, mówił o nieufności do labiryntu. Lecz prawdą jest, że labirynt, czyli rzeczywistość, a przynajmniej jakaś jej część, zredukowana do mapy natychmiast umiera. Kiedy pisze się: hic sunt leones, lwów już tu nie ma. Sądzę, że Szymborska doskonale o tym wiedziała, już to dlatego, że chodzi tu o samą stawkę, jednocześnie odkupienie i potępienie, pewnej formalnej konstrukcji, już to dlatego, że to właśnie mówi - lepiej: ukazuje - w Labiryncie, wierszu z tomu Dwukropek, który darzę absolutną miłością (wydaje mi się, że w nim przerosła samą siebie pod każdym względem). Tak wybrzmiewa jego zakończenie, które utwierdza labirynt, a jednocześnie, pozostawia wszystko, paradoksalnie, otwarte, w zawieszeniu:

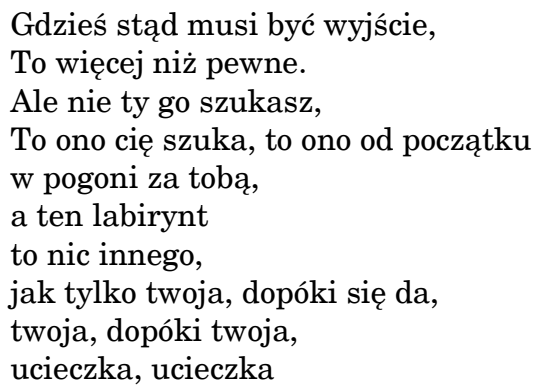

Po której stronie jesteśmy? Labiryntu czy mapy? Rzeczywistości czy poezji? By się tego dowiedzieć, musimy wciąż powracać do tej poezji. Nie, pomyliłem się - musimy wciąż powracać do życia. Chyba że, jak wskazuje na to cała poezja Szymborskiej, tkwimy w środku i to jest nasze właściwe miejsce: między labiryntem a mapą, między poezją a życiem, tak jak między końcem a początkiem, początkiem i końcem. Tak, lecz tymczasem, jak powiada Hamlet, przerwa (my powiemy: chwila) należy do mnie.

przełożyt Andrzej Zawadzki 
